\title{
Zirconium Modified Aluminide Coatings Obtained by the CVD and PVD Methods
}

\author{
Jolanta Romanowska ${ }^{1}$, Maryana Zagula-Yavorska ${ }^{1}$, Jan Sieniawski ${ }^{1}$, Janusz Markowski ${ }^{2}$ \\ ${ }^{1}$ Departament of Materials Science, Rzeszow University of Technology, Rzeszow, Poland \\ ${ }^{2}$ Faculty of Microsystem Electronics and Photonics, Wroclaw University of Technology, Wrocław, Poland \\ Email: yavorska@prz.edu.pl
}

Received October 10, 2013; revised November 8, 2013; accepted November 15, 2013

Copyright (C) 2013 Jolanta Romanowska et al. This is an open access article distributed under the Creative Commons Attribution License, which permits unrestricted use, distribution, and reproduction in any medium, provided the original work is properly cited.

\begin{abstract}
The paper presents the comparison of the structures of the zirconium modified aluminide coatings deposited on pure nickel by the CVD and PVD methods. In the CVD process, zirconium was deposited from the $\mathrm{ZrCl}_{3}$ gas phase at the $1000^{\circ} \mathrm{C}$. Zirconium thin layer ( 1 or $7 \mu \mathrm{m}$ thick) and aluminum thin layer $(1.0,0.7$ or $0.5 \mu \mathrm{m}$ thick) were deposited by the EB-PVD method. Deposition velocity was about $1 \mu \mathrm{m} / \mathrm{min}$. The layers obtained by the Electron Beam Evaporation method were subjected to diffusion treatment for $2 \mathrm{~h}$ in the argon atmosphere. The obtained coatings were examined by the use of an optical microscope (microstructure and coating thickness) a scanning electron microscope (chemical composition on the cross-section of the modified aluminide coating) and XRD phase analysis. Microstructures and phase compositions of coatings obtained by different methods differ significantly. NiAl(Zr), $\mathrm{Ni}_{3} \mathrm{Al}$ and $\mathrm{Ni}(\mathrm{Al})$ phases were found in the CVD aluminide coatings, whereas $\mathrm{Ni}_{5} \mathrm{Zr}_{2} \mathrm{Ni}_{7} \mathrm{Zr}_{2}$ and $\gamma \mathrm{Ni}(\mathrm{Al}, \mathrm{Zr}$ ) were observed in coatings obtained by the PVD method. The results indicate that the microstructure of the coating is strongly influenced by the method of manufacturing.
\end{abstract}

Keywords: CVD Method; PVD Method; Zirconium Modified Aluminide Coatings

\section{Introduction}

The improvement of engine turbines efficiency is achieved by the use of effective cooling systems of turbine blades and by diffusion protective coatings on nickel-based superalloys [1-3]. Alloyed nickel aluminides are of particular interest for use as bond coats in thermal barrier and environmental barrier coating systems, due to their strengths and abilities to form a protective aluminide oxide layer. It is the aluminum oxide layer that limits the amount of oxygen that can diffuse into critical engine components causing a catastrophic failure. This layer is also one of the most critical components of a thermal barrier (TBC) system. TBCs are used to protect superalloy engine components from the harsh environments that they are exposed to as a result of operation in gas turbine engines. Temperature in these engines can exceed $1650^{\circ} \mathrm{C}$ and metal temperature can reach $1200^{\circ} \mathrm{C}$. TBCs insulate the superalloy, thus allowing engines to work at higher temperature with higher efficiency [4-8]. Oxidation of the bond coat is a primary failure mechanism of commercial TBCs and a potential weak link for improving coatings lifetime. In most cases, bond coats are designed to form an external protective $\alpha-\mathrm{Al}_{2} \mathrm{O}_{3}$ scale during high temperature operation. Adhesion of this thermally-grown scale is necessary to maintain the ceramic top coat. Any spallation of the alumina scale results in loss of the overlying ceramic coating.

Numerous factors affect adhesion of the $\alpha-\mathrm{Al}_{2} \mathrm{O}_{3}$ scale to the metal substrate [9]. One of them is a chemical composition of the coating. Addition of small amounts of reactive elements such as $\mathrm{Zr}$, $\mathrm{Hf}, \mathrm{Y}$, or $\mathrm{Ce}$, Pt to aluminide coatings has beneficial effects on their oxidation behavior [9]. These beneficial effects include improvement of adhesion of alumina scales and reduction of oxide scale growth rate which results in elongation of the coating and TBC lifetime [9-12]. Zirconium co-deposited with aluminum on the nickel superalloy by the CVD process was developed by Onera and Snecma [22]. Zirconium provided by the $\mathrm{ZrCl}_{2} \cdot 8 \mathrm{H}_{2} \mathrm{O}$ activator [13] locates far below the coating surface, at the interface between the $\beta$-NiAl coating and the interdiffusion zone. This interface corresponds to the initial surface of the superalloy and zirconium deposition occurs at the begin- 
ning of the process. The interdiffusion zone consists of the $\beta$-NiAl matrix and phases containing additional elements of the superalloy (Cr, Co, W, Al, Ti, Mo) [13]. During oxidation, zirconium migrates towards the surface and the $\mathrm{Zr}$ distribution in the whole oxide layer becomes homogeneous. Zirconium may migrate via $\mathrm{NiAl}$ grain boundaries, where it is known to segregate [14]. Thus, $\mathrm{Zr}$ present in the oxide can be expected to modify the stress relief by reducing the oxide creep rate. Zirconium delays the oxide scale spalling and inhibits the formation of cavities at the metal/oxide interface. There is no voiding at the metal/oxide interface, unlike in Ptmodified NiAl coatings [13]. The absence of voiding in the presence of $\mathrm{Zr}$ is expected to improve alumina adhesion on the nickel aluminide [13].

Several techniques have been employed to deposit NiAl coatings [15]. Two of them are: the electron beam physical vapor deposition (EB-PVD) $[16,17]$ and the chemical vapor deposition (CVD) methods [18-21].

In this study, the structure of zirconium-modified aluminide coatings deposited by these two methods on pure nickel is analyzed.

\section{Experimental}

The commercial nickel of $99.95 \%$ wt purity was used in this study. The cylindrical samples of the $20 \mathrm{~mm}$ diameter and $4 \mathrm{~mm}$ high were cut and grounded up to $\mathrm{SiC}$ No 1000 , degreased in ethanol, ultrasonically cleaned and finally aluminized.

The aluminide coatings were made using the CVD equipment BPXPR0325S manufactured by IonBond company (Figure 1). The aluminizing process was conducted for $2 \mathrm{~h} \mathrm{[21]}$ and $5 \mathrm{~h}$. Aluminum chloride vapor $\left(\mathrm{AlCl}_{3}\right)$ was produced in an external generator I (Figure 1), at $330^{\circ} \mathrm{C}$ according to the reaction: $2 \mathrm{Al}+6 \mathrm{HCl} \rightarrow 2 \mathrm{AlCl}_{3}+$ $3 \mathrm{H}_{2}$. Then the saturating atmosphere was transported in a stream of hydrogen gas into the CVD reactor, where nickel samples were placed. The $\mathrm{AlCl}_{3}$ vapor reacted with the nickel and grains of intermetallic phase NiAl were formed according to the reaction: $2 \mathrm{AlCl}_{3}+2 \mathrm{Ni}+$

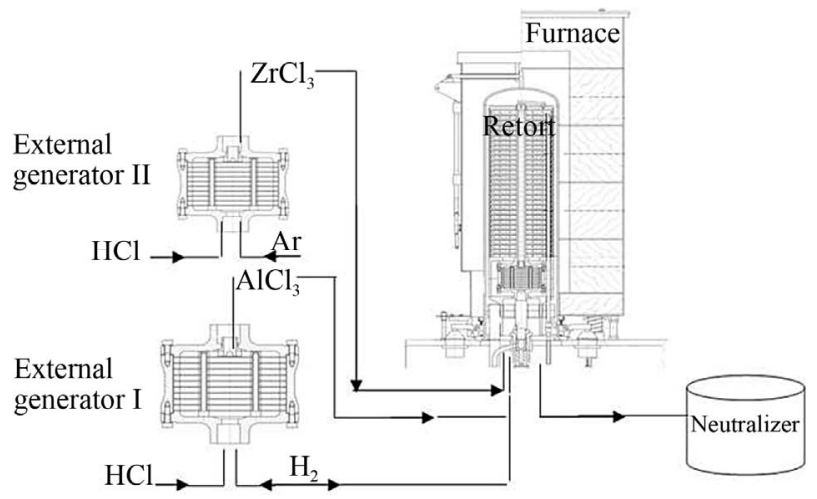

Figure 1. An equipment for the CVD method.
$3 \mathrm{H}_{2} \rightarrow 2 \mathrm{AlNi}+6 \mathrm{HCl}$.

The aluminizing process with zirconium consisted of the following steps:

I- heating from the room temperature up to $900^{\circ} \mathrm{C}$;

II- aluminizing at $900^{\circ} \mathrm{C}$ for $20 \mathrm{~min}$;

III- heating from $900^{\circ} \mathrm{C}$ to $1020^{\circ} \mathrm{C}$;

$\mathrm{IV}$ - aluminizing at $1020^{\circ} \mathrm{C}$ for $5 \mathrm{~min}$;

$\mathrm{V}$-aluminizing and zirconizing at $1020^{\circ} \mathrm{C}$ for $90 \mathrm{~min}$ [21] and $270 \mathrm{~min}$;

VI-aluminizing at $1020^{\circ} \mathrm{C}$ for $10 \mathrm{~min}$;

VII-cooling samples with the furnace to $500^{\circ} \mathrm{C}$;

VIII-cooling samples in the air atmosphere.

Zirconium chloride vapor $\left(\mathrm{ZrCl}_{3}\right)$ was produced in an external generator II (Figure 1) at $440^{\circ} \mathrm{C}$ according to the reaction: $2 \mathrm{Zr}+6 \mathrm{HCl} \rightarrow 2 \mathrm{ZrCl}_{3}+3 \mathrm{H}_{2}$. The saturation atmosphere was transported in a stream of hydrogen gas into the CVD reactor, where nickel samples were placed.

Zirconium doping aluminizing process was described by the Onera and Snemca [22], but our process is different from the process presented in [22]. In both processes $\mathrm{Zr}$ and $\mathrm{Al}$ are co-deposited on the substrate, but in the Onera and Snemca process $\mathrm{Zr}$ is provided by the $\mathrm{ZrOCl}_{2}$ activator, whereas in the process described in this work, by the $\mathrm{ZrCl}_{3}$.

Zirconium thin layer (1 or $7 \mu \mathrm{m}$ thick) and aluminum thin layer $(1.0,0.7$ or $0.5 \mu \mathrm{m}$ thick) were deposited by the EB-PVD method. In this method, the material to evaporate (placed in a water-cooled $\mathrm{Cu}$ crucible) is melted by focused high energy electron beam. Power density in electron beam spot (on the surface of the material) can reach over $40 \mathrm{~kW} / \mathrm{cm}^{2}$ and any material around the spot can be easily evaporated. Well-cooled walls of crucible protect the material against contamination by $\mathrm{Cu}$. After the evaporation process, the material can be easily evacuated (it does not stick to the crucible). An additional advantage of this method is that material can have any form (wire, sheet pieces, pellets, etc.) and can be easily supplemented in the crucible. For this work, Balzers ESQ 110 (four hearts crucible) electron beam evaporator was used. Electrons emitted from a hot tungsten cathode (Figure 2) are initially focused by the Wehnelt electrode and than are accelerated by the electric field to the anode and achieve energies up to $10 \mathrm{keV}$. Under the influence of the magnetic field, electron beam is focused and deflected (by an angle of $270^{\circ}$ ), forming a high energy electron spot on the surface of the material in the crucible. Due to four hearts crucible of ESQ 110, it is possible to obtain up to 4 different material layers on the substrate in one vacuum process.

All layers were deposited on motionless Ni substrates. The distance between the evaporating source (crucible) and substrates was $150 \mathrm{~mm}$.

Under this conditions, the rate of the material deposition (v) depends on the electron beam power: 


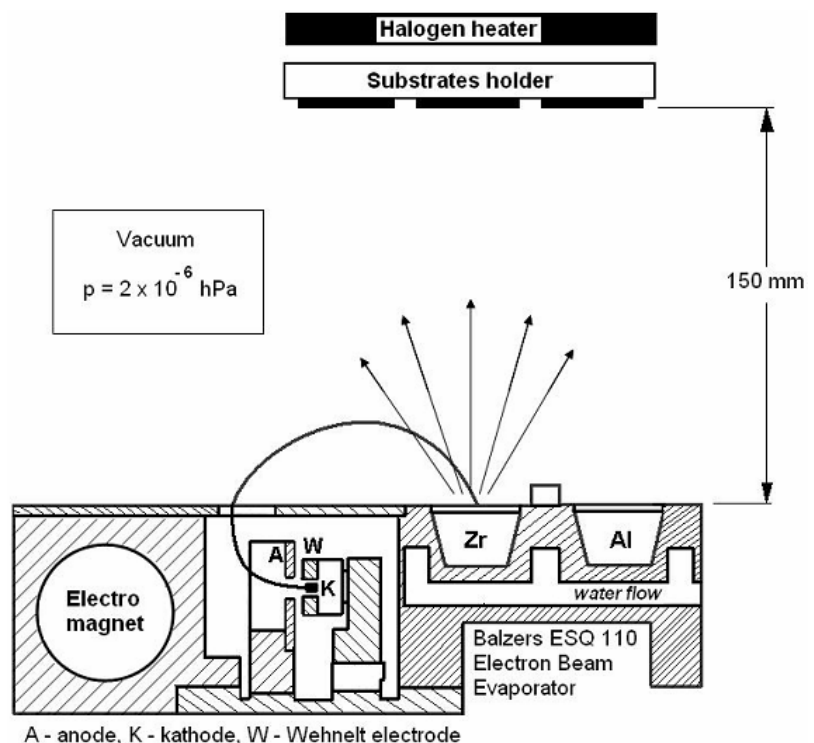

Figure 2. Scheme of the apparatus of the EB-PVD method.

$$
\mathrm{P}_{\mathrm{E}}=\mathrm{U}_{\mathrm{E}} \times \mathrm{I}_{\mathrm{E}}
$$

where $\mathrm{U}_{\mathrm{E}}$ - anode voltage and $\mathrm{I}_{\mathrm{E}}$ - electron beam current (cathode emission current).

Deposition rates for $\mathrm{Zr}$ and $\mathrm{Al}$ were established as follows:

$\mathrm{V}_{\mathrm{Zr}}=1.0 \mu \mathrm{m} / \mathrm{min}$ for $\mathrm{I}_{\mathrm{E}}=310 \mathrm{~mA}, \mathrm{U}_{\mathrm{E}}=9.5 \mathrm{kV}$;

$\mathrm{v}_{\mathrm{Al}}=1.2 \mu \mathrm{m} / \mathrm{min}$ for $\mathrm{I}_{\mathrm{E}}=300 \mathrm{~mA}, \mathrm{U}_{\mathrm{E}}=9.5 \mathrm{kV}$.

Technological stages for $\mathrm{Zr}$ and $\mathrm{Al}$ coatings deposition were as follows:

- Substrates cleaning in a detergent and placing in a substrates holder;

- Pumping the chamber to $\mathrm{p}=2 \times 10^{-6} \mathrm{hPa}$;

- Substrate heating to $300^{\circ} \mathrm{C}\left(\mathrm{t}_{\mathrm{H}}=20 \mathrm{~min}\right)$;

- Evaporation of the 1-st layer ( $\mathrm{Zr}$ or $\mathrm{Al})$ with the mentioned above rate (v) to obtain the proper coating thickness (evaporation time $\mathrm{t}_{\mathrm{E}}=0.5 \mathrm{~min} \div 7 \mathrm{~min}$ depends on v);

- Crucible rotation (changing the position to another material);

- Evaporation of the second coating ( $\mathrm{Zr}$ or Al) with the mentioned above rate $(\mathrm{v})$ to obtain the proper layer thickness (evaporation time $\mathrm{t}_{\mathrm{E}}=0.5 \mathrm{~min} \div 7 \mathrm{~min}$ depends on v);

- Cooling substrates to $50^{\circ} \mathrm{C}$ (about 1 hour);

- Venting the chamber.

The obtained layers were subjected to diffusion treatment at $1050^{\circ} \mathrm{C}$ for $2 \mathrm{~h}$ in the argon atmosphere.

The microstructure of the coatings obtained in the CVD and EB-PVD processes were examined by the use of Nikon Epiphot 300 optical microscope, a scanning Hitachi S-3400N scanning electron microscope (SEM) and an energy dispersive spectroscope (EDS). The coatings thicknesses' were determined by means of NIS-
Elements software. Eight measurements for each sample were performed.

Phase composition of the coatings was investigated using the ARL X'TRA X-ray diffractometer, equipped with a filtered copper lamp with the voltage of $45 \mathrm{kV}$. Microhardness was measured by the Nano-Indentation Tester (NHT) manufactured by CSM. The Berkowicz indentor was used, the pyramid angle was $65^{\circ}$ and the maximal load was $10 \mathrm{mN} / \mathrm{min}$.

\section{Results and Discussion}

The microstructures of zirconium doped aluminide coatings deposited for 2 and 5 hours by the CVD method at $1020^{\circ} \mathrm{C}$ are presented in Figures 3 and 4, and the chemical compositions on the cross sections are shown in Tables 1 and 2 .

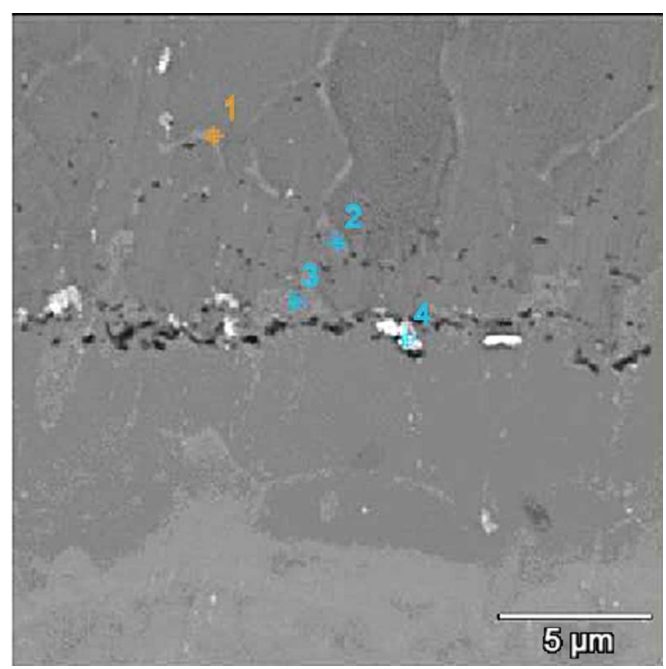

Figure 3. Microstructure of the zirconium-doped aluminide coating deposited by CVD method at $1020^{\circ} \mathrm{C}$ for $2 \mathrm{~h}$.

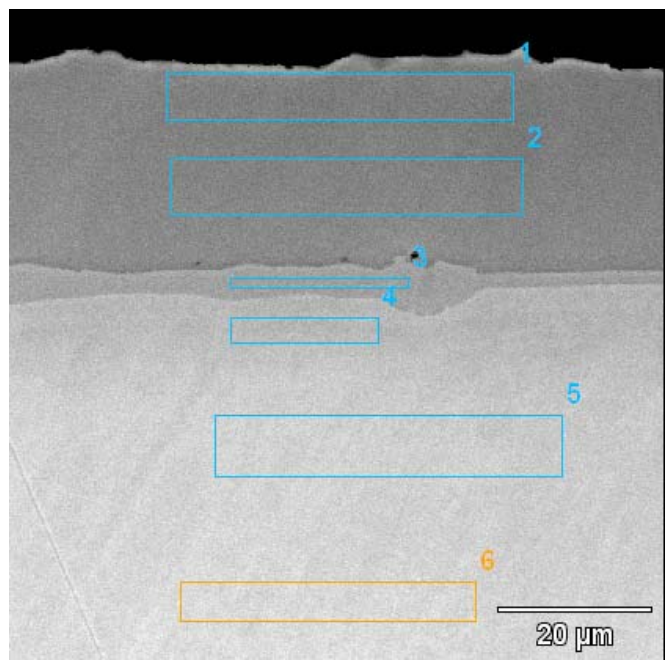

Figure 4. Microstructure of the zirconium-doped aluminide coating deposited by CVD method at $1020^{\circ} \mathrm{C}$ for $5 \mathrm{~h}$. 
Table 1. Chemical composition on the cross-section of zirconium doped aluminide coating deposited by CVD process method at $1020^{\circ} \mathrm{C}$ temperature for $2 \mathrm{~h}$.

\begin{tabular}{cccc}
\hline \multirow{2}{*}{ Point } & \multicolumn{3}{c}{ Elements content, \% at } \\
\cline { 2 - 4 } & $\mathrm{Al}$ & $\mathrm{Ni}$ & $\mathrm{Zr}$ \\
\hline 1 & 40.50 & 59.26 & 0.24 \\
2 & 38.79 & 61.21 & 0.00 \\
3 & 26.17 & 72.66 & 1.17 \\
4 & 9.99 & 89.19 & 0.82 \\
\hline
\end{tabular}

Table 2. Chemical composition on the cross-section of zirconium doped aluminide coating deposited by CVD process method at $1020^{\circ} \mathrm{C}$ temperature for $5 \mathrm{~h}$.

\begin{tabular}{cccc}
\hline \multirow{2}{*}{ Point } & \multicolumn{3}{c}{ Elements content, \% at } \\
\cline { 2 - 4 } & $\mathrm{Al}$ & $\mathrm{Ni}$ & $\mathrm{Zr}$ \\
\hline 1 & 40.50 & 59.26 & 0.24 \\
2 & 38.79 & 61.21 & 0.00 \\
3 & 26.17 & 72.66 & 1.17 \\
4 & 9.99 & 89.19 & 0.82 \\
5 & 0.98 & 99.02 & 0.00 \\
6 & 0.57 & 99.43 & 0.00 \\
\hline
\end{tabular}

Microstructures of both coatings are similar. In both cases, it is a triple zone structure. Chemical compositions of zones, see Tables $\mathbf{1}$ and $\mathbf{2}$, correspond to $\beta$-NiAl, $\gamma^{\prime}-$ $\mathrm{Ni}_{3} \mathrm{Al}$ and $\gamma-\mathrm{Ni}(\mathrm{Al})$. The presence of these phases was confirmed by the XRD analysis [21] (Figure 5).

The elongation of the time of zirconium-aluminizing process from 2 to $5 \mathrm{~h}$ leads to increase of the coating thickness from 30 to $50 \mu \mathrm{m}$. The EDS analysis and concentration profiles of the cross-section of the coating showed the nickel outward diffusion from the substrate and the inward aluminum diffusion from the surface to the nickel substrate (Figure 6). In the coating deposited for two hours zirconium was found in "inclusions" between the $\beta-\mathrm{NiAl}$ and the $\gamma^{\prime}-\mathrm{Ni}_{3} \mathrm{Al}$ zones (Figure 3 and Table 2). Aluminum diffused inward to the nickel substrate, whereas zirconium diffused to the $\beta-\mathrm{NiAl} / \gamma^{\prime}-\mathrm{Ni}_{3} \mathrm{Al}$ layers' border, where $\mathrm{Zr}$ atoms substitute for $\mathrm{Al}$ atoms in the $\beta$-NiAl phase [23]. The Kirkendall porosity was observed on the border between $\beta$-NiAl and $\gamma^{\prime}-\mathrm{Ni}_{3} \mathrm{Al}$ layers (Figure 3). The value of nickel diffusion coefficient is bigger than aluminum diffusion coefficient $\left(\mathrm{D}_{\mathrm{Ni}}>\mathrm{D}_{\mathrm{Al}}\right)$. The unbalanced flux of nickel and aluminum atoms results in the differences in microvolume and causes stresses in the diffusion zone. The microvolume is reduced in the area of higher nickel concentration and vacancies are formed. When the number of vacancies is high, vacancies coagulate and therefore pores are being formed. This way, the Kirkendall porosity is generated [23].

Zirconium does not form any inclusions but dissolves in the coating's phases in the coating deposited for 5 hours (Figure 4). The Kirkendall porosity was not ob-

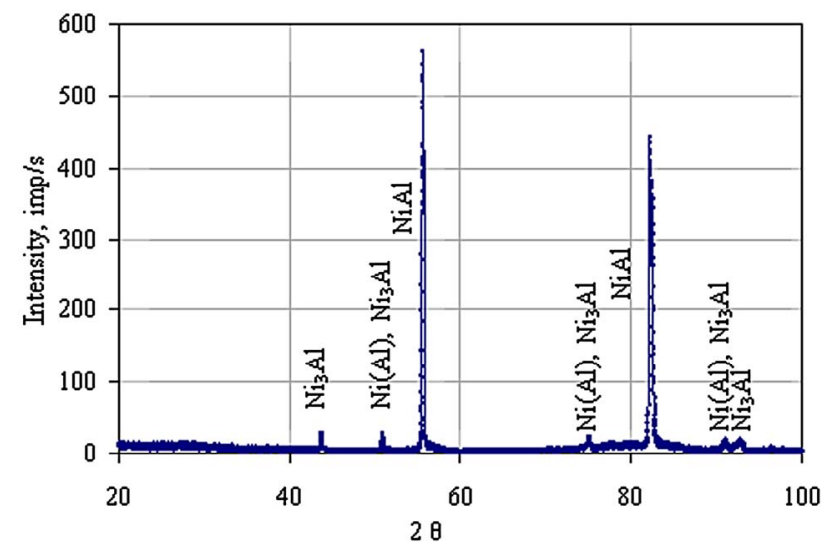

Figure 5. The XRD pattern of the zirconium-doped aluminide coating deposited by CVD method at $1020^{\circ} \mathrm{C}$ for 5 hours.

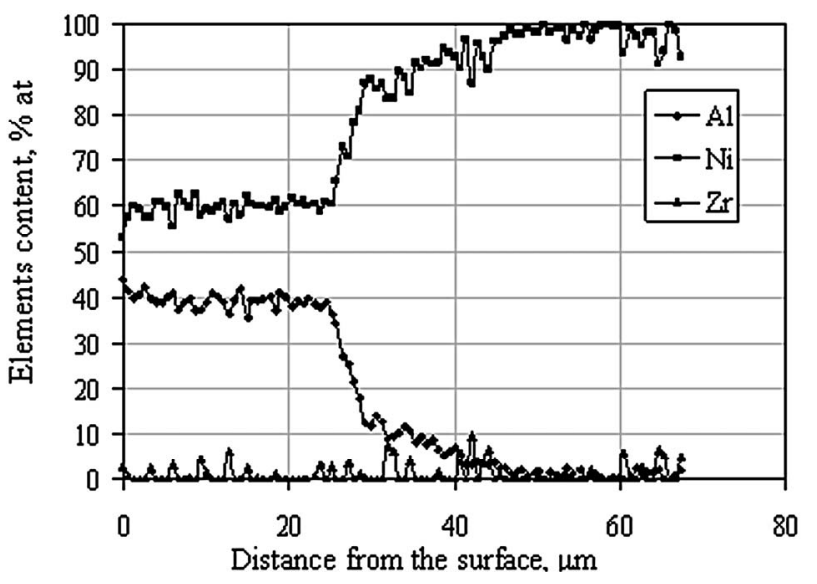

Figure 6. EDS linear analysis on the cross-section of the zirconium-doped aluminide coating deposited by CVD method at $1020^{\circ} \mathrm{C}$ for 5 hours.

served. The absence of Kirkendall voids may be an evidence of balanced flow of elements forming the coating. It is worth mentioning that when the CVD process lasted for 2 hours, zirconium was situated in inclusions at the interface between $\beta$-NiAl and $\gamma^{\prime}-\mathrm{Ni}_{3} \mathrm{Al}$ phase and Kirkendall porosity was observed. After 5 hours process, neither inclusions nor Kirkendall porosity were observed. It seems that elongation of the diffusion time balanced the diffusion flux.

The microstructure of coatings obtained after the diffusion treatment of the $\mathrm{Zr} 7 \mu \mathrm{m}$ thick and $\mathrm{Al} 0.5 \mu \mathrm{m}$ thick and the $\mathrm{Zr} 7 \mu \mathrm{m}$ thick and $\mathrm{Al} 0.7 \mu \mathrm{m}$ thick layers deposited by EB-PVD method is similar (Figures 7 and 8). The coating consists of two zones: an outer $(2-3 \mu \mathrm{m}$ thick) zone and an internal (13-12 $\mu \mathrm{m}$ thick) one. On the top of the coating the proportion of $\mathrm{Ni}, \mathrm{Al}$ and $\mathrm{Zr}$ corresponded to $\gamma$-Ni(Al,Zr) phase (Figure 7 and Table 3 Point 1, Figure 8 and Table 4 Point 1 ).

The chemical composition of the inner zone distributed below the $\gamma-\mathrm{Ni}(\mathrm{Al}, \mathrm{Zr})$ phase corresponds to the $\mathrm{Ni}_{7} \mathrm{Zr}_{2}$ 


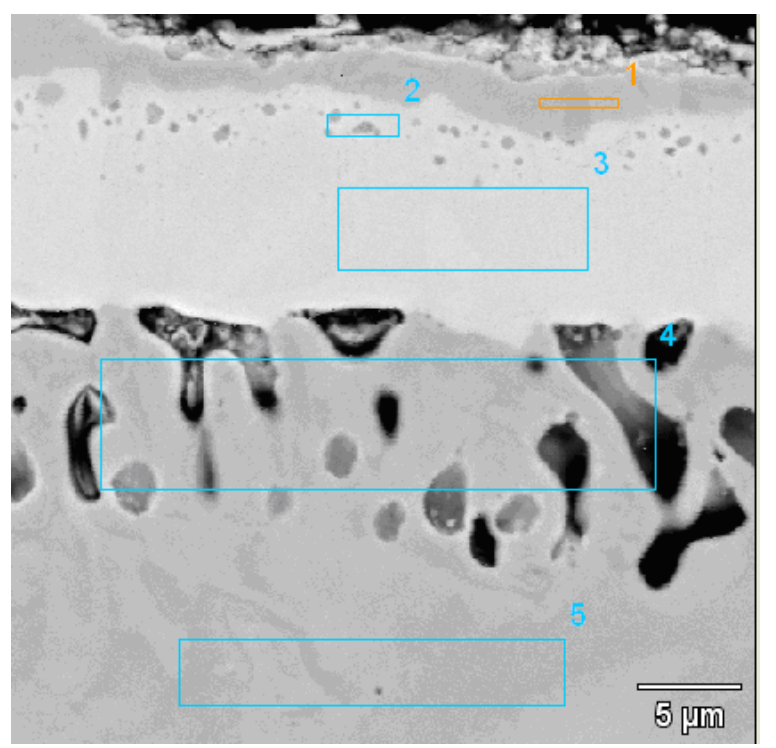

Figure 7. Microstructure of the $\mathrm{Zr} 7 \mu \mathrm{m}$ thick and Al 0.5 $\mu \mathrm{m}$ thick coatings deposited by EB-PVD method after the diffusion treatment.

Table 3. Chemical composition on the cross-section of the $\mathrm{Zr} 7 \mu \mathrm{m}$ thick and Al $0.5 \mu \mathrm{m}$ thick coatings after the diffusion treatment.

\begin{tabular}{cccc}
\hline \multirow{2}{*}{ Point } & \multicolumn{4}{c}{ Chemical composition, \% at } \\
\cline { 2 - 4 } & $\mathrm{Al}$ & $\mathrm{Ni}$ & $\mathrm{Zr}$ \\
\hline 1 & 3.91 & 95.22 & 0.87 \\
2 & - & 76.33 & 23.67 \\
3 & - & 83.64 & 16.36 \\
4 & 2.81 & 96.17 & 1.02 \\
5 & - & 100 & - \\
\hline
\end{tabular}

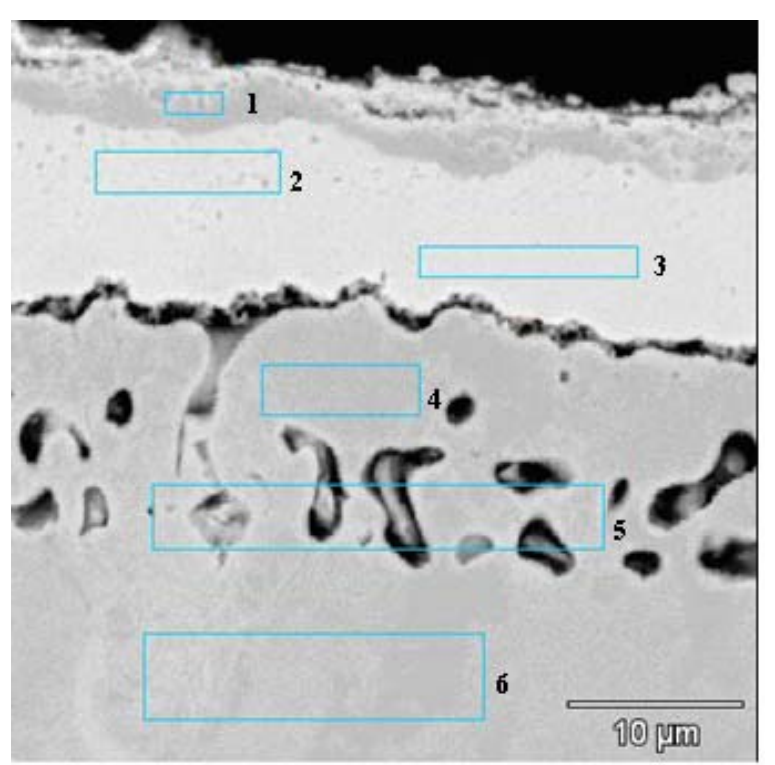

Figure 8. Microstructure of the $\mathrm{Zr} 7 \mu \mathrm{m}$ thick and $\mathrm{Al} 0.7$ $\mu \mathrm{m}$ thick coatings deposited by EB-PVD method after the diffusion treatment.
Table 4. Chemical composition on the cross-section of the $\mathrm{Zr} 7 \mu \mathrm{m}$ thick and Al $0.7 \mu \mathrm{m}$ thick coatings after the diffusion treatment.

\begin{tabular}{cccc}
\hline \multirow{2}{*}{ Point } & \multicolumn{3}{c}{ Chemical composition, \% at } \\
\cline { 2 - 4 } & $\mathrm{Al}$ & $\mathrm{Ni}$ & $\mathrm{Zr}$ \\
\hline 1 & 4.00 & 95.22 & 0.78 \\
2 & - & 79.60 & 20.40 \\
3 & - & 82.23 & 17.77 \\
4 & 3.84 & 96.16 & - \\
5 & 3.43 & 95.20 & - \\
6 & - & 100 & - \\
\hline
\end{tabular}

phase (Figure 7 and Table 3 Point 2, Figure 8 and Table 4 Point 2) and $\mathrm{Ni}_{5} \mathrm{Zr}$ phase (Figure 7 and Table 3 Point 3, Figure 8 and Table 4 Point 3). Below the presence of the $\gamma-\mathrm{Ni}(\mathrm{Al}, \mathrm{Zr}$ ) phase was detected (Figure 7 and Table 3 Point 4, Figure 8 and Table 4 Point 4, 5). The presence of the $\mathrm{Ni}_{7} \mathrm{Zr}_{2}$ and $\mathrm{Ni}_{5} \mathrm{Zr}$ phases was confirmed by the XRD analysis (Figures 9 and 10).

There are observed many voids in the substrate just above the coating. Kirkendall porosity is an evidence of an unbalanced flow of nickel, aluminum and zirconium atoms in the diffusion zone. Kirkendall voids are generated below the original interface, so the outward nickel diffusion is faster than the inward zirconium and aluminum diffusion.

The diffusion treatment of $\mathrm{Zr}$ layer $1 \mu \mathrm{m}$ thick and $\mathrm{Al}$ layer $1 \mu \mathrm{m}$ thick leads to formation of intermetallic phases enriched with nickel and zirconium (Figure 11. Point $2 \%$ - $84.97 \%$ at $\mathrm{Ni}, 12.95 \%$ at $\mathrm{Zr}$; Point $4 \%-84.27 \%$ at Ni, $15.02 \%$ at $\mathrm{Zr}$ ) (Figure 11 and Table 5). According to $\mathrm{Ni}-\mathrm{Zr}$ phase diagram, chemical composition of these phases corresponds to $\mathrm{Ni}_{5} \mathrm{Zr}$ phase (Figure 12). EDS linear analysis on the cross-section indicates that intermetallic phases are formed $5-7 \mu \mathrm{m}$ below the coating's surface (Figure 13).

After the diffusion treatment process, zirconium formed intermetallic phase $\mathrm{Ni}_{5} \mathrm{Zr}$, whereas aluminum did not form any phases with nickel or zirconium. Its concentration is almost the same along the investigated cross section $(20 \mu \mathrm{m})$ (Figure 13), so it may be assumed that aluminum dissolves in nickel and solid solution $\gamma-\mathrm{Ni}(\mathrm{Al})$ is being formed.

The differences in the hardness of the coatings deposited by CVD and EB-PVD methods (Table 6) were found. The biggest hardness is in the internal zone of coatings. The increase of hardness values in the internal zone of coatings is due to the intermetallic phase formation.

\section{Conclusions}

The coatings' microstructure is influenced by several factors such as the deposition method, the diffusion time and the amount of zirconium. Molar volumes of diffusing 


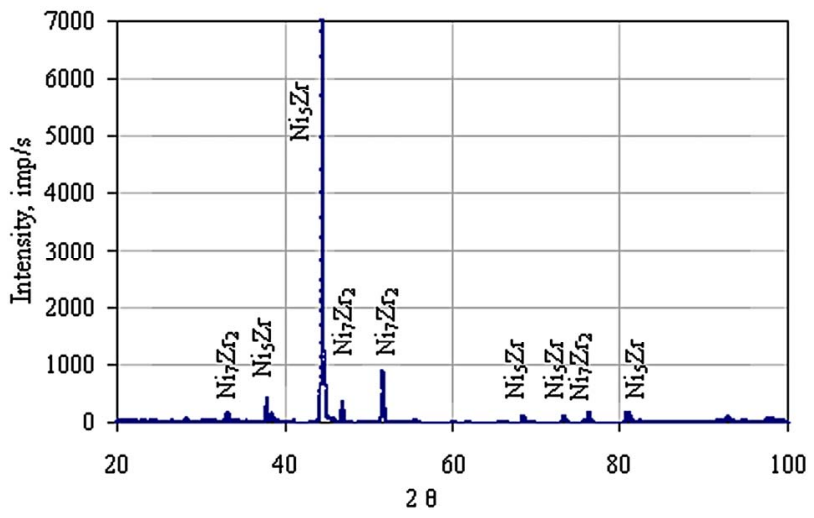

Figure 9. The XRD pattern of the $\mathrm{Zr} 7 \mu \mathrm{m}$ thick and Al 0.5 $\mu \mathrm{m}$ thick coatings after the diffusion treatment.

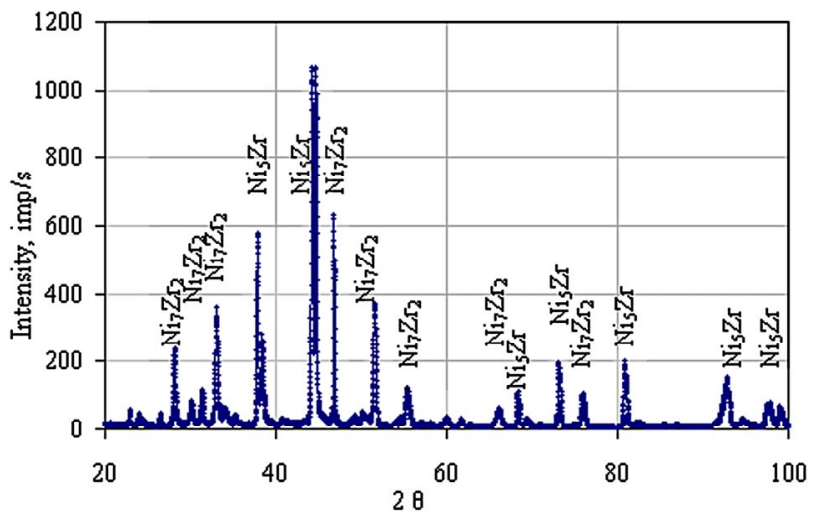

Figure 10. The XRD pattern of the $\mathrm{Zr} 7 \mu \mathrm{m}$ thick and Al 0.7 $\mu \mathrm{m}$ thick coatings after the diffusion treatment.

elements are different $\left(\mathrm{v}_{\mathrm{Ni}}=6.59 \times 10^{-6}, \mathrm{v}_{\mathrm{Al}}=10.6 \times\right.$ $\left.10^{-6}, \mathrm{v}_{\mathrm{Zr}}=14.02 \times 10^{-6} \mathrm{~m}^{3} / \mathrm{mol}\right)$, which may cause the unbalanced flux of elements. When the diffusion time is long and the zirconium amount is small (as for the 5 hours CVD process), nickel, aluminum and zirconium fluxes are balanced, and there are no voids or intermetallic inclusions and zirconium dissolves in the coating (see Figures 4-6). When the diffusion time is shorter (2 hours, CVD process), the coatings thickness is smaller, zirconnium is found in $\mathrm{NiAl}(\mathrm{Zr})$ inclusions between the $\beta$-NiAl and the $\gamma^{\prime}-\mathrm{Ni}_{3} \mathrm{Al}$ zones and the Kirkendall porosity is observed on the border between $\beta$-NiAl and $\gamma^{\prime}-\mathrm{Ni}_{3} \mathrm{Al}$ layers' (Figure 3), [21]. It is an evidence of the unbalanced nickel and zirconium flux. Hardness of NiAl and $\mathrm{Ni}_{3} \mathrm{Al}$ zones is about $446-498 \mathrm{HV}$.

In coatings obtained by the diffusion treatment of $\mathrm{Zr} 1$ $\mu \mathrm{m}$ thick and $\mathrm{Al} 1 \mu \mathrm{m}$ thick layers deposited by the EB-PVD method, inclusions of the $\mathrm{Ni}_{5} \mathrm{Zr}$ phase (hardness about $647 \mathrm{HV}$ ) were found at a certain distance from the sample's surface, but no porosity was observed. Aluminum does not form any intermetallic phases with nickel but dissolves in the nickel substrate (Figures 12 and 13). The increase of the zirconium layer thickness to $7 \mu \mathrm{m}$ resulted in unbalanced zirconium and nickel fluxes.

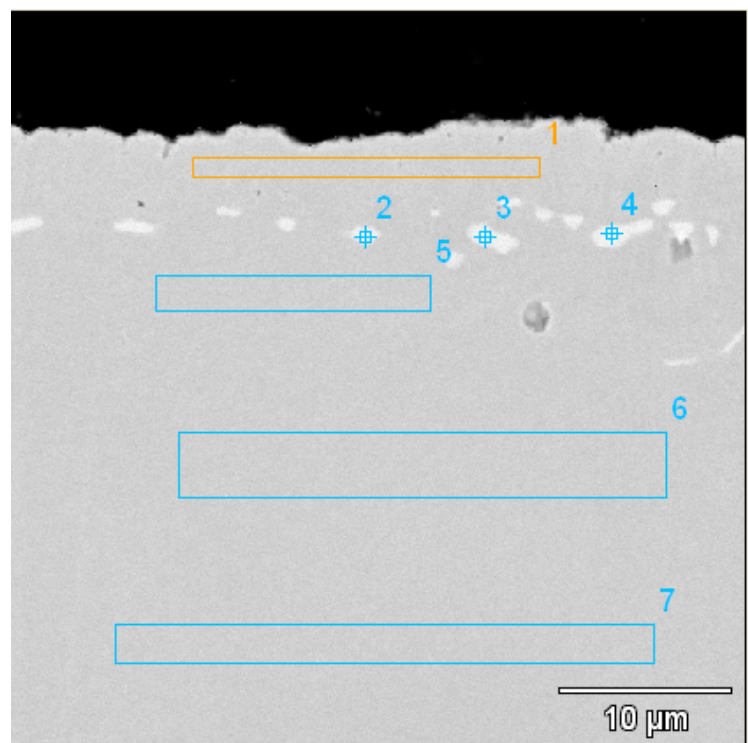

Figure 11. Microstructure of the $\mathrm{Zr} 1 \mu \mathrm{m}$ thick and Al $1 \mu \mathrm{m}$ thick coating deposited by EB-PVD method after the diffusion treatment.

Table 5. Chemical composition on the cross-section of the $\mathrm{Zr} 1 \mu \mathrm{m}$ thick and Al $1 \mu \mathrm{m}$ thick coating after the diffusion treatment.

\begin{tabular}{cccc}
\hline \multirow{2}{*}{ Point } & \multicolumn{3}{c}{ Elements content, \% at } \\
\cline { 2 - 4 } & $\mathrm{Al}$ & $\mathrm{Ni}$ & $\mathrm{Zr}$ \\
\hline 1 & 5.72 & 94.04 & 0.23 \\
2 & 2.08 & 84.97 & 12.95 \\
3 & 2.72 & 89.12 & 8.16 \\
4 & 0.71 & 84.27 & 15.02 \\
5 & 4.76 & 93.74 & 1.50 \\
6 & 0.85 & 99.15 & - \\
7 & 0.13 & 99.87 & - \\
\hline
\end{tabular}

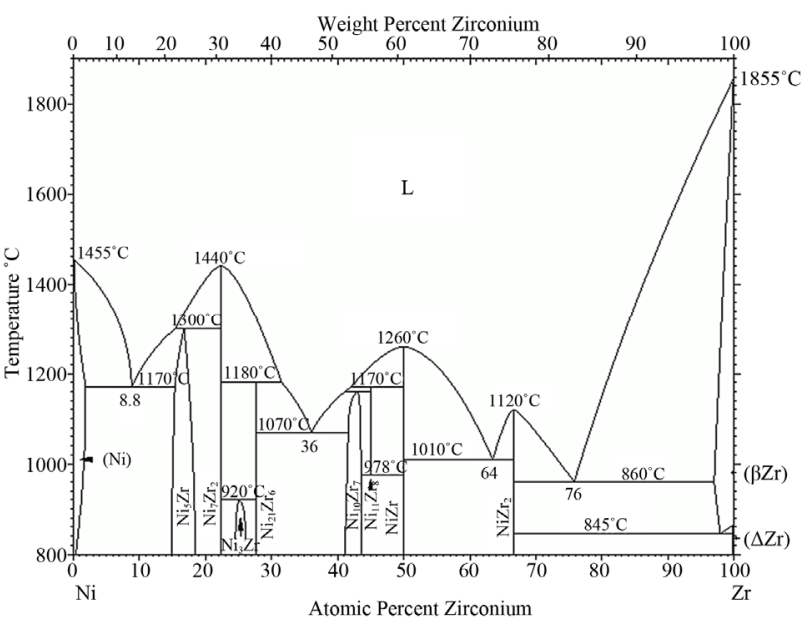

Figure 12. The Ni-Zr phase diagram [24].

There are many voids in the substrate just below the substrate surface (Figures 7 and 8) and inclusions of $\mathrm{Ni}_{7} \mathrm{Zr}_{2}$ 
Table 6. Vickers hardness distribution on the cross-section of the zirconium-aluminide coatings deposited by the CVD and EB-PVD methods.

\begin{tabular}{cccc}
\hline \multirow{2}{*}{ Method of coating deposition } & \multicolumn{3}{c}{ Vickers hardness HV } \\
\cline { 2 - 4 } CVD & Outer zone/phase & Internal zone/phase & Ni-substrate \\
\hline EB-PVD $(\mathrm{Zr} 7 \mu \mathrm{m} / \mathrm{Al} 0.5 \mu \mathrm{m}$ thick + diffusion treatment) & $446 / \mathrm{NiAl}$ & $498 / \mathrm{Ni}_{3} \mathrm{Al}$ & 208 \\
$\mathrm{~EB}-\mathrm{PVD}(\mathrm{Zr} 7 \mu \mathrm{m} / \mathrm{Al} 0.7 \mu \mathrm{m}$ thick + diffusion treatment) & $295 / \gamma$-Ni(Al,Zr $)$ & $828 /\left(\mathrm{Ni}_{7} \mathrm{Zr}_{2} / \mathrm{Ni}_{5} \mathrm{Zr}\right)$ & 265 \\
EB-PVD $(\mathrm{Zr} 1 \mu \mathrm{m} / \mathrm{Al} 1 \mu \mathrm{m}$ thick + diffusion treatment) & $290 / \gamma$-Ni(Al,Zr) & $647 / \mathrm{Ni}_{5} \mathrm{Zr}$ & 211 \\
\hline
\end{tabular}

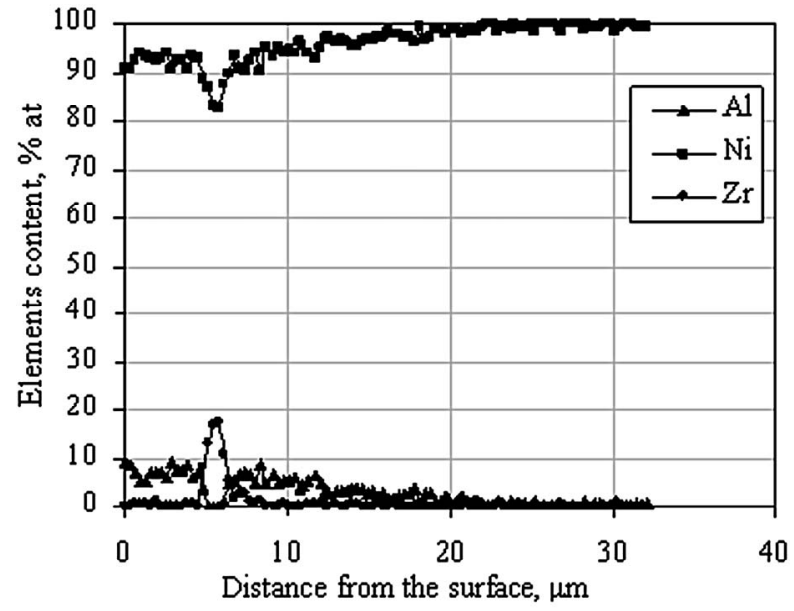

Figure 13. EDS linear analysis on the cross-section of the $\mathrm{Zr}$ $1 \mu \mathrm{m}$ thick and Al $1 \mu \mathrm{m}$ thick coating after the diffusion treatment.

and $\mathrm{Ni}_{5} \mathrm{Zr}$ intermetallic phases are formed below the coating's surface Figures 7-10). The hardness of these phases is about $762-828 \mathrm{HV}$.

\section{Acknowledgements}

The presented research was supported by the National Science Centre, Poland, project number 2011/01/DST8/ 05/036.

\section{REFERENCES}

[1] Y. Tamarin, "Protective Coatings for Turbine Blades," ASM International, Materials Park, 2002.

[2] S. Bose, "High Temperature Coating," Elsevier Inc., Burlington, 2007.

[3] G. W. Goward, "Protective Coatings-Purpose, Role and Design," Materials Science and Technology, Vol. 2, No. 10, 1986, pp. 194-200. http://dx.doi.org/10.1179/026708386790123314

[4] M. A. Bestor, R. L. Martens, R. A. Holler and M. L. Weaver, "Influences of Annealing and Hafnium Concentration on the Microstructures of Sputter Deposited $\beta$ NiAl Coatings on Superalloy Substrates," Intermetallics, Vol. 18, No. 11, 2010, pp. 2159-2168. http://dx.doi.org/10.1016/j.intermet.2010.07.001

[5] B. A. Pint, J. R. Di Stefano and I. G. Wright, "Oxidation
Resistance: One Barrier to Moving beyond Ni-Base Superalloys," Materials Science and Engineering: A, Vol. 415, No. 1-2, 2006, pp. 255-263.

http://dx.doi.org/10.1016/j.msea.2005.09.091

[6] M. Zielińska, J. Sieniawski, M. Yavorska and M. Motyka, "Influence of Chemical Composition of Nickel Based Superalloy on the Formation of Aluminide Coatings," Archives of Metallurgy and Materials, Vol. 56, No. 1, 2011, pp. 193-197. http://dx.doi.org/10.2478/v10172-011-0023-y

[7] M. Yavorska, J. Sieniawski and M. Zielińska, "Functional Properties of Aluminide Layer Deposited on Inconel 713 LC Ni-Based Superalloy in the CVD Process," Archives of Metallurgy and Materials, Vol. 56, No. 1, 2011, pp. 187-192. http://dx.doi.org/10.2478/v10172-011-0022-Z

[8] B. A. Pint, I. G. Wright, W. Y. Lee, Y. Zhang, K. Prussner and K. B. Aleksander, "Substrate and Bond Coat Compositions: Factors Affeccting Alumina Scale Adhesion," Materials Science and Engineering: A, Vol. 245, No. 2, 1998, pp. 201-211. http://dx.doi.org/10.1016/S0921-5093(97)00851-4

[9] M. Zagula-Yavorska, J. Romanowska and J. Sieniawski, "Platinum Diffusion in Pure Nickel," Wulfenia Journal, Vol. 20, 2013, pp. 222-234.

[10] B. M. Warnes, "Reactive Element Modified Chemical Vapor Deposition Low Activity Platinum Aluminide Coatings," Surface and Coatings Technology, Vol. 146147, 2001, pp. 7-12. http://dx.doi.org/10.1016/S0257-8972(01)01363-9

[11] B. A. Pint, "The Role of Chemical Composition on the Oxidation Performance of Aluminide Coatings," Surface and Coatings Technology, Vol. 188-189, 2004, pp. 71-78.

[12] Y. Wang, M. Suneson and G. Sayre, "Synthesis of HfModified Aluminide Coatings on Ni-Base Superalloys," Surface \& Coatings Technology, Vol. 206, No. 6, 2011, pp. 1218-1228. http://dx.doi.org/10.1016/j.surfcoat.2011.08.031

[13] S. Hamadi, M. Bacos, M. Poulain, A. Seyeux, V. Maurice and P. Marcus, "Oxidation Resistance of a Zr-Dopped NiAl Coating Thermochemically Deposited on a NickelBased Superalloy," Surface \& Coatings Technology, Vol. 204, No. 6-7, 2009, pp. 756-760. http://dx.doi.org/10.1016/j.surfcoat.2009.09.073

[14] D. Larson and M. Miller, "Atom Probe Field-Ion Microscopy Characterization of Nickel and Titanium Aluminides," Materials Characterization, Vol. 44, No. 1-2, 2000, pp. 159-165.

http://dx.doi.org/10.1016/S1044-5803(99)00049-2 
[15] T. Rhys-Jones, "Coatings for Blade and Vane Applications in Gas Turbines," Corrosion Science, Vol. 29, No. 6, 1989, pp. 623-646.

http://dx.doi.org/10.1016/0010-938X(89)90104-2

[16] B. Movchan, "Functionally Graded EB-PVD Coatings," Surface and Coatings Technology, Vol. 149, No. 2-3, 2002, pp. 252-262. http://dx.doi.org/10.1016/S0257-8972(01)01439-6

[17] H. Guo, L. Sun, H. Li and S. Gong, "High Temperature Oxidation Behavior of Hafnium Modified NiAl Bond Coat in EB-PVD Thermal Barrier Coating System," Thin Solid Films, Vol. 516, No. 16, 2008, pp. 5732-5735.

[18] A. Nowotnik, J. Sieniawski, M. Góral, M. Pytel and K. Dychton, "Microstructure and Kinetic Growth of Aluminide Coatings Deposited by the CVD Method on Re 80 Superalloy," Archives of Materials Science and Engineering, Vol. 55, No. 1, 2012, pp. 22-28.

[19] M. Zagula-Yavorska, J. Sieniawski and T. Gancarczyk, "Some Properties of Platinum and Palladium Modified Aluminide Coatings Deposited by CVD Method on
Nickel-Base Superalloys," Archives of Metallurgy and Materials, Vol. 57, No. 2, 2012, pp. 504-509. http://dx.doi.org/10.2478/v10172-012-0052-1

[20] J. Romanowska, "Aluminum Diffusion in Aluminide Coatings Deposited by the CVD Method on Pure Nickel," Calphad, in Press, 2013.

http://dx.doi.org/10.1016/j.calphad.2013.09.003

[21] J. Romanowska, M. Zagula-Yavorska and J. Sieniawski, "Zirconium Influence on Microstructure of Aluminide Coatings Deposited on Nickel Substrate by CVD Method," Bulletin of Materials Science, 2013.

[22] M. Bacos, J. Dorvaux, S. landais, O. Lavigne, R. Mevrel, M. Poulain, C. Rio and M. Vidal-Setif, "10 Years-Activities at Onera on Advanced thermal Barrier Coatings," ONERA-Aerospace Lab Journal, Vol. 3, 2011, pp. 1-14.

[23] G. Bozolo, R. Noebe and F. Honect, "Modeling of Ternary Element Site Substitution in NiAl," Intermetallics, Vol. 8, No. 1, 2000, pp. 7-18. http://dx.doi.org/10.1016/S0966-9795(99)00066-7 